\title{
SYMPOSIUM: WALT WHITMAN FACING WEST
}

\author{
Editor's Note
}

The symposium "Walt Whitman Facing West," supported in part by a grant from the California Council for the Humanities, was held on the campus of the California State University, Fresno, over the weekend of March 20-22, 1992. One of several conferences celebrating the centennial of the poet's death, the Fresno State symposium hosted a number of internationally known Whitman scholars as well as several specialists on other authors and areas of interest. The participants included (in alphabetical order) Fernando Alégria, Harold Aspiz, Roger Asselineau, Calvin Bedient, Gene Bluestein, William Bedford Clark, José Elgorriaga, Betsy Erkkila, William Everson, Ed Folsom, Albert J. Gelpi, Susan Goodman, Linda Hamalian, Dickran Kouymjian, Richard D. Lehan, Philip Levine, Jerome Loving, Carrol Peterson, Juan Serrano, Carol Zapata Whelan, and James Woodress. The co-directors of the conference were Jerome Loving and Carol Zapata Whelan; the assistant director was Wendy Costa.

The conference got underway with a performance by Whitman Chautauquan Carrol Peterson, whose pre-conference appearance at a local high school was filmed as part of the CBS "Sunday Morning" feature (broadcast April 19, 1992) on the Whitman centennial celebrations around the country. Peterson's performance was followed by a reading of Spanish and Latin-American poets by José Elgorriaga, accompanied by the music of world-renowned Flamenco guitarist Juan Serrano. Recent National Book Award winner Philip Levine read from Leaves of Grass and read responses from several contemporary poets (including himself).

The approaches to Whitman fell into the following categories: 1) the reception of Whitman's democratic themes abroad and at home, 2) Whitman: sexuality and gender, 3) Whitman: the literary connections, 4) Whitman's poetry and America today. The final session featured the aged and ailing poet William Everson, who said among other things that he had become a poet in the Fresno State library (as a student in the 1930s coming upon a volume of Robinson Jeffers), that Allen Ginsberg was the first contemporary poet to rediscover Whitman's rhythm, and that a new romantic age lay just around the turn of the century. It was a poignant and moving performance which brought the gathering about as close toWhitman as was possible one hundred years after his death. 
This issue of the Walt Whitman Quarterly Review prints three of the original papers delivered at the symposium. They link in new ways (in the case of Saroyan, the newness is the connection itself) Whitman to major writers of our own century: Edith Wharton, Robert Penn Warren, and (Fresno-born) William Saroyan. The common theme of the essays is that each writer found him- or herself in the life and writings of what one contributor calls "the Sage of Camden." Actually, what all three also found in Whitman was their own American appreciation for democracy's contradictions.

Following these essays is a remarkable essay on "The Sleepers" by the co-director of the conference, Carol Zapata Whelan.

Texas AEM University

JEROME LOVING 